\title{
Socio-economic benefit of rubber agroforestry system for improved livelihood in Edo State, Nigeria
}

\author{
C. Okwu-Abolo ${ }^{1 *}, J . A$. Soaga $^{2}$, S.O. Idoko ${ }^{1}$ \\ ${ }^{1}$ Rubber Research Institute of Nigeria, Edo State, Nigeria \\ ${ }^{2}$ University of Agriculture, Abeokuta, Ogun State, Nigeria
}

\begin{abstract}
Rubber Agroforestry System (RAS) is an innovative farming system contributing significantly to the livelihood of smallholders in Edo State. Data for this study were collected from 120 rubber smallholder farmers having a contiguous 2 hectares farmland with the aid of structured questionnaire using multistage sampling technique with a 3 -stage design. Data collected were analyzed using descriptive, inferential, and budgetary analysis. The result revealed that majority of the RAS farmers were males, with an average mean age of 49 years and most of the RAS farmers had some level of education, they attained secondary and tertiary education with an average number of 8.3 years in education. Furthermore, the total annual revenue earned by the respondents was $\$ 992,500(\$ 2,756.94)$ with a mean annual net income of $\$ 527,003$ (\$1,463.90) while the return per naira invested was 1.69. This shows that for every 1 invested in the cropping combination in the RAS, there was a return of 69 kobo in the study area. Thus, RAS provides income and employment for smallholder community to be self-sufficient and economically independent. This study concludes that respondents valued RAS as an innovative sustainable agroforestry system capable of generating income and employment. Government therefore should leverage through adequate fiscal policy to enable easy credit facility by farmers
\end{abstract}

Keywords: Rubber Agroforestry System (RAS), profitability, livelihood, smallholder's farmer.

\section{Introduction}

Rubber cultivation is an age long practice in Nigeria but has suffered decline, from 248,900 ha to 154,000 ha of land area, since the mid-1970s. The decline in hectarage was as a result of the low rubber prices in the international market and over-dependence on revenue from petroleum [7]. Rubber plantation owners especially the smallholder farmers contribute over $70 \%$ of the world's natural rubber, these Rubber smallholders are seeking ways of improving the productivity of rubber farming system which has been of imminent

\footnotetext{
* Corresponding Author: cokwuabolo@yahoo.com; +234 8053313252
} 
importance. Some of the inherent challenges faced by these Rubber smallholders are the uneconomical land size and the long gestation period of Rubber that deprived farmers of a sustainable income during the immature phase of Rubber. This situation has remained a disincentive to rubber farmers and has made rubber enterprise unattractive. Thus, the need arises to promote a system that maximizes the available land space by balancing food production and maintaining good ecological environment for sustainable production and management of other forest resources [5]. Hence, a timely adoption of appropriate plantation management practices that is capable of utilizing the under-utilized land resources and increasing the revenue base of the enterprise is important to the attainment of the drive to increase rubber production in Nigeria. One possible approach that may assist rubber farmers to improve their income while maintaining rubber production is to intercrop rubber with indigenous fruit trees and arable crops, this farming system is commonly known as Rubber Agroforestry.

Rubber Agroforestry System (RAS) is an innovative approach to improve the lives of smallholders by developing and promoting model farms with quality planting materials of high yielding Rubber clones to meet farmers' requirements and also creates opportunities for income enhancement through integration of arable crops on the inter-rows during the immature phase of Rubber [4]. Rubber Agroforestry offers a good opportunity which exploits the synergies that combine the characteristic advantages associated with forestry and agricultural practices. This land use systems have proven to be profitable and environmentally sustainable $[1,4]$ makes maximum use of resources and serves as a source of revenue for farmers especially during the gestation period of Rubber. Furthermore, Rubber agroforestry systems are considered unique in terms of their potential benefits, such as provision of food, employment, tree products, reduces susceptibility to market crashes, ecological services and has proven as the best option to the expansion of Rubber cultivation in Nigeria.

Thus, this study was designed to evaluate the socio-economic benefit of rubber agroforestry system among smallholder farmers for improved livelihood in Nigeria.

\section{Methodology}

Study area: The study was carried out in two Local Government Areas (L.G.A.) namely; Ovia South West and Ikpoba Okha in Edo State, Nigeria. Edo State lies between longitudes $05^{\circ} 04^{\prime} \mathrm{E}$ and $06^{\circ} 43^{\prime} \mathrm{E}$ and latitudes $05^{\circ} 44^{\prime} \mathrm{N}$ and $07^{\circ} 34^{\prime} \mathrm{N}$. It covers a land area of about $19,794 \mathrm{~km}^{2}$. The State is bounded on the north by Kogi State, on the west by Ondo State, in the south by Delta State and on the east by Anambra State. The vegetation of Edo State varies from the north to the south. In the north, the area is mainly derived savanna while in the south it's mainly the rainforest type of which parts of it has been deforested to give way to secondary growth. The soil profile in the Esan plateau is made up of diverse vegetation, savanna in the north and rainforest in the south which supports the growth of oil palm and rubber that has displaced a lot of the original forests.

Sampling Method: A multistage sampling technique with a 3-stage design was used in selecting respondents for this study using a structured questionnaire. The first stage involved identifying and selecting the two LGA that is known for Rubber production on a large commercial scale. Secondly, the purposive selection of the communities within the primary selection units and finally, the third stage, was selecting the respondents randomly from each community given a total of 120 respondents selected for this study as shown in Table 1. Primary data were collected through personal interview and the use of structured questionnaire administered to respondents. Data collected were analyzed with both descriptive and inferential statistics. 
Table 1. Distribution of Established model farms in Edo State

\begin{tabular}{|c|c|c|c|}
\hline State & LGA & Community & Respondents \\
\hline \multirow{3}{*}{ Edo } & \multirow{2}{*}{ Ovia South West } & Iguoriakhi & 30 \\
\cline { 3 - 4 } & & Iyowa & 30 \\
\cline { 2 - 4 } & \multirow{2}{*}{ Ikpoba Okha } & Imasabor & 30 \\
\cline { 3 - 4 } & & Obagie Nevbosa & 30 \\
\hline Total & & & 120 \\
\hline
\end{tabular}

Budgetary Analysis: Budgetary analytical tool (Gross Margin and net farm income) was used to assess the profitability of rubber agroforestry systems among the respondents. The returns to farmer's labour and management are expressed both in Naira per hectare ( $\mathrm{N} / \mathrm{ha})$ and US dollar per hectare (\$/ha). Costs comprise both fixed and variable cost. Fixed Cost (FC) includes cost of farm shed and plantations. While variable Cost (VC) include: cost of labour, chemicals and other variable inputs. Returns are revenues that accrue from the sale of produce. Generally, profit was determined by:

$$
\text { Gross Profit }(G P)=T R-T V C
$$

Where; TR = Total Revenue ( $)$, is given by Py*Y;

Py is the price/unit of the product,

$\mathrm{Y}=$ Quantity/Output,

TVC $=$ Total Variable Cost

$$
\text { Net Profit }(N P)=G P-T F C
$$

Where; GP = Gross Profit; TFC = Total Fixed Cost;

$$
\text { Total Cost }(T C)=T V C+T F C
$$

Profitability Ratio: Profitability ratio was used in analyzing economic variables like Gross Income (GI), Net income (NI) and Rate of Return on Investment (RORI) [12, 9]. These tools are defined and computed as follows; Net income (NI): This is defined as gross income (GI) less Gross cost (GC).

Mathematically:

$$
\text { Net Income }(N I)=\text { Gross Income }(G I)-\text { Gross Cost }(G C)
$$

Where; GI = Total quantity of product sold over the period at prevailing market price; $\mathrm{GC}=$ Total cost of production (cost of labour, chemicals and other variable inputs.).

Rate of return on investment (RORI): This reveals the level of profitability of an investment, it is an important criterion in determining the choice of investment to embark on. It is determined using the following relationship:

$$
\text { RORI }=\frac{\text { Profit } \times 100}{\text { Total cost }}=\frac{T R-T C \times 100}{T C}
$$

Where; Profit $=$ TR - TC

$$
\mathrm{TC}=\mathrm{TVC}+\mathrm{TFC}
$$




\section{Results and discussion}

\subsection{Demographic data of rubber agroforestry farmers}

Table 2 presents the demographic data of rubber agroforestry farmers in Edo State. The average mean age of the farmers was 49 years, with an average number of 8.3 years in education. Rubber trees has an economic rotation age of 40 years, it is expected that farmers within this age range are most likely to engage in the cultivation of Rubber [8]. Also, the respondents were literate and knowledgeable in agricultural practices, in addition, these farmers can be trained further on practices that will improve the cultivation and management of the rubber agroforestry farm. The average mean farm size of the respondents was 4.9 hectarage, with a mean of 8.9 years in Rubber agroforestry farming. The planting density of Rubber stands is approximately $500 \mathrm{ha}^{-1}$, Thus, the least hectarage to be used for Rubber farming is 2 ha for those farmers who venture into Rubber as a business enterprise. Buttressed further that land is the primary source of livelihood for the farmers and the land size and distribution dictates its utilization [2]. Land distribution is an important issue in rural development, where land is insufficient to support the basic needs of a farm family, there is a tendency for communities to encroach into protected areas. Hence, the need to adopt and promote rubber agroforestry practices that will intensify and diversify the system to create a more integrated, productive, profitable, healthy and sustainable land-use system [4]. The integration and interaction of trees and crops in the same land space promotes agroecosystem functions [11]. Following the innovative approach of the Rubber Agroforestry System, famers need to be abreast with new information and technical know-how of RAS farming and related agricultural activities; this innovative approach requires interactions of the farmers with extension officers having similar mandate. Thus, extension officers visited these model farms with an average mean of 2.5 visits per quarter of each year. Proximity to farm land is also an imperative determinant especially in the sales of farm produce, the result from the study revealed that the average distance of farmers' residence to model farm was $1.9 \mathrm{~km}$.

Table 2. Demographic data of Rubber Agroforestry farmers

\begin{tabular}{|c|c|}
\hline Socio-economic variable & Mean \\
\hline Age (years) & 49 \\
\hline Education & 8.3 \\
\hline Farm size & 4.9 \\
\hline Farming experience (years) & 8.9 \\
\hline Extension officer visit to model farms & 2.5 \\
\hline $\begin{array}{c}\text { Distance of farmers residence to model farm } \\
(\mathrm{km})\end{array}$ & 1.9 \\
\hline
\end{tabular}

\subsection{Ranking choice of preferred crops for rubber agroforestry farms}

Table 3 presents the farmers' choices of crops for rubber agroforestry system. Cassava was ranked first having been selected by $35.8 \%$ of the respondents followed by maize $(26.6 \%)$, Honey (12.5 \%), Pineapple (7.5 \%), Plantain (5.8 \%) and Bush mango (4.1\%). The farmers' choices of crops were based on the revenue realized from intercrops, food need and cultural background of the farmers.

Rubber Agroforestry Systems (RAS) in the study area can be categorized into three main systems namely: Rubber (food) intercrop, Rubber mini-livestock, and Rubber shade tolerant crops in accordance with the farmers preference. Amongst these categories, Rubber 
(food) intercrop was the most practiced system by the farmers according to the frequency of mention - Rubber and cassava intercrop, Rubber and maize intercrop and Rubber and honey bee in a matured plantation. These three cropping combinations are most commonly practiced in that order. RAS promotes the development of alternative livelihood options through the production of improved planting materials and mini-livestock in a matured Rubber plantation [1], thus, agroforestry significantly contributes to diversification of outputs from a farm unit. These goods and services derived from RAS contribute to the subsistence livelihood of the farmers as well as maintenance and sustainability of their ecosystem. One of the most important functions of agroforestry system is the diversity of outputs [13], agroforestry system can provide essential goods and services such as tree products for on-farm consumption or sale [6]. Environmental services are provided by trees and their physical environment interacting with one another to benefit man [3]. Thus, rubber agroforestry provides goods and services and could be valued beyond welfare but as a valuable resource on its own, providing additional environmental services to ensure ecosystem stability.

Table 3. Ranking of choice preferred crops/mini-livestock for Rubber intercropping

\begin{tabular}{|c|c|c|c|}
\hline \multicolumn{2}{|c|}{ Crop/mini-livestock } & \multirow{2}{*}{ Percentage } & \multirow{2}{*}{ Rank order } \\
\cline { 1 - 2 } Scientific name & Local name & & $1^{\text {st }}$ \\
\hline Manihot esculenta & Cassava & 35.83 & $2^{\text {nd }}$ \\
\hline Zea mays & Maize & 26.67 & $5^{\text {th }}$ \\
\hline Musa x paradisiaca & Plantain & 5.83 & $4^{\text {th }}$ \\
\hline Ananas comosus & Pineapple & 7.5 & $3^{\text {rd }}$ \\
\hline Apis mellifera & Honey & 12.5 & $6^{\text {th }}$ \\
\hline Irvingia wombulu & Bush mango & 4.17 & $8^{\text {th }}$ \\
\hline Telfairia occidentalis & Pumpkin & 2.5 & $7^{\text {th }}$ \\
\hline Abelmoschus esculentus & Okro & 3.22 & $9^{\text {th }}$ \\
\hline Oryctolagus cuniculus & Rabbit & 1.67 & \\
\hline
\end{tabular}

\subsection{Costs and return analysis of a Rubber Agroforestry System}

The profitability of a RAS in the study area was actualized using gross margin analysis and Rate of Return on Investment (RORI). Table 4 shows that the total cost (TC) incurred in the establishment and planting of the intercrop in a RAS was $\$ 465,496.8(\$ 1,293.05)$ while the total variable (TVC) cost incurred was $\$ 369,000$ (\$1,025) representing $79.3 \%$ of the total cost. The total fixed cost (TFC) incurred was $\$ 96,496.8$ (\$268.05) representing $20.7 \%$ of the total cost. Also, the gross margin and net farm income was of $623,500(\$ 1,731.94)$ and $\$ 527,003.2$ (\$1,463.90) respectively. The gross returns from the various intercrop in a RAS offers alternative sources of income to rubber farmers and further minimizes crop failures and environmental shocks during the immature phase of rubber. It was also deduced from the result in Table 4 that a rubber farmer can earn an average annual revenue of 992,500 (\$2,756.94) given mean annual net income of the rubber farmers to be $\$ 527,003.2$ (\$1,463.90). The return on naira invested was $\$ 1.69$, this shows that for every \#1 invested in the cropping combination in the RAS, there was a return of 69 Kobo in the study area. The benefit-cost ratio obtained was 2.69 , thus, the study therefore concluded that the rubber agroforestry system in Nigeria is viable and profitable. 
Table 4. Summary of Costs and Return analysis

\begin{tabular}{|l|c|c|}
\hline \multicolumn{1}{|c|}{ Variable } & \multicolumn{2}{c|}{ Total Amount } \\
\hline & Naira ( $)$ & US Dollar (\$) \\
\hline Total Revenue & $\$ 992,500$ & $\$ 2,756.94$ \\
\hline Total Variable Cost & $\$ 369,000$ & $\$ 1,025$ \\
\hline Total Fixed Cost & $\$ 96,496.8$ & $\$ 268.05$ \\
\hline Total Cost (TFC + TVC) & $\$ 465,496.8$ & $\$ 1,293.05$ \\
\hline Gross Margin (R+ TVC) & 623,500 & $\$ 1,731.94$ \\
\hline Net Income (GM - TFC) & $\$ 527,003.2$ & $\$ 1,463.90$ \\
\hline RORI & 1.69 & $\$ 0.47$ \\
\hline RORI \% & & \\
\hline BCR & & \\
\hline$* * * \$ 1=\$ 360$ & & \\
\end{tabular}

\section{Conclusion}

This study analyzed the socio-economic benefits of rubber agroforestry among smallholder's farmers. The result of the study shows that Rubber Agroforestry System (RAS) contributes to the welfare of subsistence RAS farmers and the livelihood of the respondents as well as maintenance and sustainability of the ecosystem. Thus, in other to manage the existing lands available more efficiently, there is need to encourage and promote RAS in the study area and other locations in Nigeria using the model of RAS in Edo State; as this study has shown that the existing farmland can be made more productive by either increasing the yields of the existing land with good quality crop or rehabilitating degraded farmland to bring it back into full production. Therefore, this study concludes RAS is an innovative sustainable rubber agroforestry system capable of generating income and employment. It is therefore suggested that government can leverage on existing RAS model through adequate fiscal policy to enable easy credit facility for farmers.

\section{References}

1. Asaah E., Okwu, C., Esekhade, T., Osazuwa, E. and Onaiwu, B. Rubber Agroforestry: perspectives for smallholdings in Nigeria. Policy Brief No. 26, pp 14. Published by World Agroforestry Centre, and Rubber Research Institute of Nigeria (2014).

2. El Tahir, B.A. and Vishwanath, A. Journal of Geoscience and Environment Protection. 3:38-56(2015). http://dx.doi.org/10.4236/gep.2015.39005

3. DEFRA. Climate change strategies framework. Department for Environment, Food and Rural Affairs. Departmental Report 2007 (2007). http://www.defra.gov.uk

4. Esekhade, T., Idoko, S., Mesike, S., Ubani, S., Balogun, F.E., Igbinosun, F., Okwu, C. and Asaah, E. Rubber Agroforestry options in Nigeria. Policy Brief No. 23. p. 14 Published by World Agroforestry Centre, and Rubber Research Institute of Nigeria (2014).

5. Idumah, F.O. and Akintan, A.O. Journal of holticulture and forestry. 6,8:6471(2014).

6. ITTO. Earning More from The Forest. Tropical Forest Update. A newsletter from the Intrnational Tropical Timber Organization to promote the conservation and sustainable development of tropical forests. $\mathbf{2 3 , 2}$ (2014). 
7. Micheal, M. M., Lai, K.S., Yusoff, K. J. Mol. Biol. Biotechnol. 14:1-17(2006).

8. Okwu, C. Economic and Ecosystem Services Valuation in a Rubber Agroforestry Systems in Edo and Delta States, Nigeria. Ph.D. degree thesis. Department of Forestry and Wildlife Management, Federal University of Agriculture, Abeokuta, Ogun State, Nigeria. p. 183 (2019).

9. Olaleye, D.O., Abegunde, A.A., Ebehikhalu, N. Global J. Hum. Soc. Econ. 15,2:206-215(2015).

10. Tchoundjeu, Z., Asaah, E., Anegbeh, P.O., Degrande, A., Mbile, P., Facheux, C., Tsobeng, A., Atangana, A.R. and Ngo-Mpeck, M.L. Putting participatory domestication into practice in West and Central Africa. For. Tree Live. 16:5370(2006).

11. Tee, N.T. and Labo, I. J. Res. For. Wildlife. Environ. 2,2:99-104(2010).

12. Young, A. Agroforestry for Soil Conservation. CAB International, Wallingford. Nair (1989).

13. P.K.R. Journal of Environmental Quality. 40:784-790(2011). http://dx.doi.org/10.2134/jeq2011.0076 